\title{
Current trends in the construction of sports infrastructure facilities, taking into account the direction of development of the international Olympic movement
}

\author{
Vladimir Kalmanovich ${ }^{1 *}[0000-0001-7637-4496]$, Olga Kalimullina ${ }^{2}$ [0000-0002-8466-2874], Ruslan \\ Garifullin ${ }^{10000-0001-9182-0474]}$, Ilgizar Sazgetdinov ${ }^{\text {[0000-0003-3907-4157] }}$, and Irina Bitcheva ${ }^{3 \text { [0000- }}$ \\ 0002-7111-3219] \\ ${ }^{1}$ Kazan State University of Architecture and Engineering, 420043, Zelenaya st., Kazan, Russia \\ ${ }^{2}$ Volga Region State University of Physical Culture Sports and Tourism, 420138, Universiade \\ Village, Kazan, Russia \\ ${ }^{3}$ Kazan state institute of culture, 420059 , Orenburg tract st., Kazan, Russia
}

\begin{abstract}
The study aims to assess current trends in the construction of sports infrastructure, considering the development and improvement vectors of the Olympic movement. Materials and methods. The study utilizes literature analysis, statistical methods, expert assessment method and legal analysis. Results. Trends in the development of sports infrastructure facilities for the Olympic Games have been identified and substantiated. The currentdifficulties regarding organizing and holding of the Olympic Games and the uprising contradictions in the activities of international sports organizations have been structured. Analysis of trends in the development of the Olympic movement in the XXI century and recent decisions of the International Olympic Committee revealed particular problems in the organization of the Games. The proposed new model of the modern Olympic Games allowing to overcome problems and contradictions of the Olympic movement is described. Conclusion. The modern stage of development of the Olympic movement is characterized by a number of contradictions and problems that need to be solved: gigantism of the Olympic Games, subjectivity of refereeing at sports competitions, safety at sports events, etc. The proposed model of the organization of the Olympic Games in the form of long-term competitions during the Olympic Year may help to overcome existing contradictions.

Keywords: the crisis of the Olympic movement, the International Olympic Committee, international sports federations, a new model of the modern Olympic Games.
\end{abstract}

\footnotetext{
*Corresponding author: volek71@yandex.ru
} 


\section{Introduction}

Analysis of the scientific and methodological literature and official statistics shows that four periods can be distinguished in the development of the Olympic movement. [1-5] The first period (1896-1916) is characterized by the holding of five Olympic Games (OG) on the European $(n=4)$ and American continents $(n=1)$, with the number of participants ranging from 241 to 2407; The Sixth Olympics was not held due to the First World War. The number of participating countries ranged from 14 to 28. The Olympic Games program was extended for several weeks and varied from Games to Games. The very concept of Olympic Games was not attractive enough. [6-12] The Games of the First Period intensified the process of establishing international sports organizations and promoted the unification of competition rules in various sports, stimulating the development of sports infrastructure. [13-17]

During this period, they began to record world records and other sporting achievements, and to develop uniform requirements for sports facilities.

The second period (1920-1944) is characterized by nine Olympic Games, including five summers and four winters. $[18,19]$ The number of participating countries has increased to 49. The number of athletes participating in Olympic Games ranged from 2,622 to 3,963 in Summer Olympic Games; 258-649 in Winter Olympics. XII and XIII Games were not held due to the Second World War [20].

The novelties of the period are: the division of the Winter and Summer Olympic Games, the streamlining of the activities of the IOC Executive Committee, the improvement of the Olympic Games programme, the construction of the Olympic Village in preparation for the Olympic Games, the emergence of some OG attributes (Olympic oath, demonstration), increasing women's participation in OG, introduction of the practice of organizing training sessions in the process of preparing for the OG, etc. [21, 22]. During this period there was an active growth of the prestige of Olympic sport, intensive development of theory of sports training, intensification of scientific research in sport, etc. [23].

In the third Period of the Olympic movement (1948-1988), 11 Summer and Winter Olympic Games were held on four continents of the world (Europe, America, Asia and Australia), with OG membership reaching 8,387 in Summer OG and 1,423 in winter OG by 1988. At the end of this period, 159 countries participated in the Summer OG and 57 in the Winter OG [24]. Important characteristics of this period are: the entry of the Soviet Union into the Olympic movement and the active participation of the USSR in the struggle for the Olympic medals; development of marketing programmes by IOC to popularize the Olympic movement and attract funding to it, attempts to use OGfor political purposes, etc. [25]. The ever-increasing competition on the global sports scene has contributed to the improvement of the scientific and methodological support system for Olympic training [26, 27].

The fourth period (from 1992 to the present) coincides with fundamental changes on the political map of the world (the break-up of the USSR, the unification of Germany) and is characterized by the emergence of new member countries, the breeding of Summer and Winter games in different years, the establishment of intergovernmental organizations participating in the organization of the Olympic movement (Court of Arbitration for Sport, World Anti-Doping Agency, IOC Ethics Committee, etc.) and the leap in sports performance in individual sports, the professionalization and commercialization of sports, the rejuvenation of sports for higher achievements, the feminization of sports, etc [28-30]. 


\section{Materials and methods}

To assess current trends in the construction of sports infrastructure, taking into account the development and improvement of the Olympic movement, as well as trends in the development of the modern Olympic movement, the following methods were used: analysis of scientific and methodological literature, statistical methods, method of expert evaluations, legal analysis. Data from open sources, official statistics, analysis of the statutes of relevant organizations, content analysis of official websites and legal and regulatory documents were used on the problem of research.

\section{Results and discussion}

Analysis of specialized scientific and methodological literature and official websites of organizations involved in the training of athletes shows that most researchers agree that the modern Olympic movement is in crisis.

The arguments are as follows: cases of subjective judgment; doping of sports results; aggressive behavior of fans; «gigantism» of the Olympic Games and others.

These events are a consequence of the deep systemic crisis of the Olympic movement, which makes it relevant to research the direction of the Olympic movement on the planet.

The Olympic Games were a prestigious event for which the strongest powers of the world competed.

The crisis began to manifest itself and grow at the end of the third and during the fourth period. The Games created in the XIX century as a complex sports and athletic contest in 9 types of sport with participation of 12 countries, in our opinion, need to be reformed, both structurally and in organizational, informational, financial, administrative and sports.

An analysis of the trends of the fourth period of the Olympic movement and recent IOC decisions revealed the following challenges for the Olympic Games in the XXI century:

1. The problem of construction of infrastructure, sports facilities and «Olympic village» for stagingGames.

(The high cost of the enterprise, the compactness of the construction requires the demolition of previous buildings, the resettlement of local residents, and the allocation of a huge plot of land resource.)

2. The problem of inconvenience for the indigenous population living in the locality.

(According to the practice of the Games, during 6-10 years of preparation for the Olympic Games, the city is a construction site.)

3. The cost-effectiveness of the legacy of the Olympic Games.

(In most cases, it is not possible to ensure the cost-effectiveness of operating so many sports facilities in one locality.)

4. The problem of referrals and doping.

(Due to the large number of competitions held in limited time and the fatigue of judges or their replacement by judges with less competence, the number of judicial errors increases. For the same reason, WADA commissioners are forced to carry out doping during training or rest of athletes, thus disrupting the preparation of the athlete for competitions.)

5. The problem of ensuring the safety of athletes, judges, functionaries, officials and fans. The tragic events of the 1972 Munich Olympics, in which athletes, coaches and judges of the Israeli team were captured and shot by terrorists, are an example of this.

(Due to the large congregation of people in one place, it is impossible to ensure the safety of all those present at the Olympic Games in a limited period of time, and the measures applied are very inconvenient for both athletes and fans.)

6. The problem with fans attending sports competitions. 
Due to the limited time available, competitions in 8-10 sports are held instantaneously, especially during the last days of the Olympics, and fans are forced to choose only one event.

7. The problem of buying the right to broadcast and the actual broadcasts of the competition.

For the same reason, television companies are forced to forgo the purchase of broadcasting rights for certain competitions and to record many competitions taking place in parallel. Thus, viewers lose the opportunity to receive true emotions from experiences of unknown, unpredictable results of competitions in online mode. The Olympic Committee loses revenue from the sale of broadcast rights.

8. The problem of the impossibility of including new, modern and interesting sports in the Olympic Games, due to the lack of specialized stadiums and sports grounds.

(There is a queue of international federations willing to include their sport in the Olympics, leading to corruption, lobbying in the IOC.)

It should be noted that at the last Summer Olympics in Rio de Janeiro in Brazil, rugby and golf competitions were not held because of the impossibility of erecting specialized sports facilities. Most recently, the president of the International Ice Hockey Federation, René Fanzel, stated that, owing to the lack of mutual understanding between the IOC, IIHF and NHL, future Olympic Games may be without hockey at all. The NHL is increasingly considering banning professional hockey players from the Olympics. This statement illustrates very well the crisis between the IOC, the International Sports Federations and the professional athletes' leagues.

The FIFA (International Federation of Association Football) policy towards the IOC, which is frankly provocative, the FIFA World Cup, like the Olympic Games, is held every four years and lasts 30 days longer than the Olympics. However, in order to diminish the status and eliminate competition from the Olympic Games, only under 23-year-olds are allowed to participate in them (that is, it is impossible to see at the Olympics the world stars of football of the first magnitude). Incidentally, FIFA is hosting the European Football Championship in 12 cities in 11 countries for the first time in 2020, which is one of the elements of our new Olympic model.

There is a big problem with the construction of specialized sports facilities of high quality that meet all requirements of international sports federations.

We want to propose a fundamentally new model of the Olympic Games, interaction between the IOC and the International Sports Federations and Development of the Olympic movement. Our model is aimed at solving all eight major tasks of the development of the Olympic movement that we have outlined above,to resolve the growing contradictions in the activities of IOC and the International Sports Federations; to ensure the objective work of WADA; to give a strong impetus to the development of new sports.

The model of the modern Olympic Games is to abandon them as a complex short-term local sports and athletic contest and the Olympic Year. That is, the Olympic Year occurs every 4 years, when for 365 days in different countries on different days (without overlaps) Olympic competitions (conditionally - World Championships) are held for the title of Olympic Champion (this year, the official Olympic World Championships are not held). This will make it possible to hold competitions on all continents, in different countries, in a variety of sports (not just in Olympic sports). Responsibility for the organization will rest with the International Sports Federations, operating this year under the auspices and mandate of IOC. There will be no need to build new sports facilities, Olympic villages or infrastructure. The opening and closing of the Olympic Year will be organized on January 1 and December 31, respectively. The competitions will be held at the traditional venues of each sport, where the International Federations of All Sports will be willing to meet the relevant IOC requirements for the organization of competitions in their sport, will be 
mandated to be included in the Olympic Year programme. The number of «Olympic» sports, in our opinion, will increase from 35 to about 80. Summer and Winter sports (as before 1996) will be held for one year. The IOC will set the schedule of the Olympic Games, determine the timing of the broadcast of each sport, the possibility of movement of fans and the convenient work of WADA.

\section{Conclusion}

With the implementation of the Olympic Contest model we have developed, the main problems of Olympic Games implementation will be solved; contradictions in the activities of IOC and the International Sports Federations will be resolved; a strong impetus will be given to the development of new young sports.

Expected effect of the new model of the modern international Olympic movement:

a) Modernization of existing and construction of new state-of-the-art sports infrastructure facilities, in places traditionally cultivated for each specific sport;

b) A departure from the construction of Olympic villages and a sports core of facilities concentrated in one place, with insufficient building space.

c) Multiplication of IOC revenues from the broadcasts and contributions of international sports federations;

d) The inclusion in the Olympics of all sports whose federations strive to do so;

e) Online media coverage of all competitions;

f) Implementation of the right of fans to see all competitions at the venues;

g) Organization of the work of the WADA anti-doping commissioners for athletes;

h) Establishment of the official status of international sports federations in the organization and holding of Olympic competitions.

\section{References}

1. A. Bolotnikov, R. Garifullin, V. Kalmanovich, E. Mugattarova, R. Khairullin, Development of health-saving environment at engineering university, IOP conference series. Materials Science and Engineering, 890, 1, 012172 (2020) DOI: 10.1088/1757899X/890/1/012172

2. E. Yakimova, P. Terehov, O. Salnikova, N. Ishmuhametova, Crowdsourcing as an approach to solving environmental problems by future construction engineers, IOP Conference Series: Materials Science and Engineering, 890, 1, 012174 (2020) DOI: 10.1088/1757-899X/890/1/012174

3. A. Guttmann, The Olympics: A history of the Modern Games (University of Illinois Press, Chicago, USA, 2002)

4. L. Akshayaa, V. Vishnupriya, R. Gayathri, Awareness of chronic fatigue syndrome among the college students - a survey Drug Invention Today, 11(6), 1369-1371 (2019)

5. A. P. Anishenko, A. N. Arkhangelskaia, V. A. Zaborova, M. Y. Karganov, I. B. Alchinova, M. V. Polyakova, K. G. Gurevich, Three-year dynamics of the changes in the physical fitness, anthropometric development, food preferences, and metabolic changes in the students trained according to the modified methodology of physical culture. [Trekhgodichnaia dinamika izmeneniia fizicheskoi podgotovlennosti, antropometricheskogo razvitiia, pishchevykh predpochteni i metabolicheskikh izmenenii u studentov, zanimaiushchikhsia po modifitsirovannoi metodike fizicheskoi kul'tury] Voprosy Kurortologii, Fizioterapii, I Lechebnoi Fizicheskoi Kultury, 95(4), 31-40 (2018), DOI: 10.17116/kurort20189504131 
6. T. H. Bailey, L. J. Phillips, The influence of motivation and adaptation on students'subjective well-being, meaning in life and academic performance, Higher EducationResearch and Development, 35(2), 201-216 (2016) DOI: 10.1080/07294360.2015.1087474

7. J. J. F. Breedvelt, Y. Amanvermez, M. Harrer, E. Karyotaki, S. Gilbody, C. L. H. Bockting, P. Cuijpers and D. D. Ebert, The effects of meditation, yoga, and mindfulness on depression, anxiety, and stress in tertiary education students: A meta-analysis Frontiers in Psychiatry ,10 (APR), 193 (2019) DOI: 10.3389/fpsyt.2019.00193

8. B. Butzer, M. Ebert, S. Telles, S. B. Khalsa, School-based Yoga Programs in the United States: A Survey, Advances in mind-body medicine, 29(4), 18-26 (2015)

9. J. D. De Vries, M. L. van Hooff, S. A. Geurts, M. A. Kompier, Exercise as an Intervention to Reduce Study-Related Fatigue among University Students: A Two-Arm Parallel Randomized Controlled Trial, PloS one, 11(3), e0152137 (2016) DOI: 10.1371/journal.pone.0152137

10. B. Ewert, Promoting health in schools: Theoretical reflections on the settings approach versus nudge tactics, Social Theory and Health, 15(4), 430-447 (2017) DOI: 10.1057/s41285-017-0036-32017

11. F. Lanary, One Hundred Years. The idea, the presidents, the achievements. Vol. 3. The presidencies of Lord Killanin and Juan Antonio Samaranch (Fernand Landry, Madeleine Yerles, Lausanne: CIO, 1996)

12. F. R. Zotova, To a question about modern sports development trends, Theory and practice of physical education, 2, 39-42 (2001)

13. N. A. Fudin, A. A. Khadartsev, S. V. Moskvin, Transcranial electrostimulation and serotonin laser phoresis in the athletes experiencing a combined effect of fatigue and psycho-emotional stress [Transkranial'naia élektrostimuliatsiia I lazeroforez serotonina u sportsmenov pri sochetanii utomleniiai psikhoémotsional'nogo stressa], Voprosy Kurortologii, Fizioterapii, iLechebnoiFizicheskoiKultury, 96(1), 37-42 (2019) DOI: 10.17116/kurort20199601137

14. S. Griggs, Hope and mental health in young adult college students: An integrative review, Journal of Psychosocial Nursing and Mental Health Services, 55(2), 28-35 (2017) DOI: 10.3928/02793695-20170210-042017

15. J. Forster, The Political Economy of Global Sporting Organisations (Routledge, London, 2004)

16. H. J. Lenskyj, Inside the Olimpic Industry: Power, Politics and Activism (SUNY Press, New York, 2000)

17. J. Thiel, G. Grabher, Crossing Boundaries: Exploring the London Olympics 2012 as a Field-Configuring Event, Industry and Innovation, 22 (3), 229-249 (2015)

18. J. W. Lee, A winter sport mega-event and its aftermath: A critical review of postOlympic Pyeong Chang, Local Economy, 34 (7), 745-752 (2019)

19. A. I. Kartavtseva, S. L. Sadyrin, E. A. Dergach, N. A. Bryukhanova, The use of electronic courses in the implementation of educational programs "Physical education and sport», "Applied physical education and sport» for students of the special educational department, Journal of Siberian Federal University - Humanities and Social Sciences, 14(2), 180-192 (2021). DOI: 10.17516/1997-1370-0710

20. V. R. Kuchma, L. M. Sukhareva, I. K. Rapoport, E. I. Shubochkina, N. A. Skoblina, O. Yu. Milushkina, Population health of children, risks to health and sanitary and epidemiological wellbeing of students: Problems, ways of solution and technology of the activity, GigienaiSanitariya, 96(10), 990-995 (2017) DOI: 10.18821/0016-99002017-96-10-990-995 
21. L. A. Brown, M. Cresciani, Adaptable design in Olympic construction, International Journal of Building Pathology and Adaptation, 35(4), 397-416 (2017)

22. V. Y. Lebedinsky, O. I. Kuzmina, M. D. Kudryavtsev, V. I Gruzenkin, T. G. Arutunian, Health monitoring of students of the III functional group for controlling and designing educational environment (physical education) in a non-sport university, Human Sport Medicine, 19(4), 78-91 (2019) DOI: 10.14529/hsm190410

23. M. Krogh-Christensen, Post-Olympism? Questioning Sport in the Twenty-first Century (Berg, Oxford, UK, 2004)

24. M. Margaret, Olympic Cities: Urban planning, city agendas and the world's Games, 1896 to the present (Routledge, London, UK, 2006)

25. D. M. Nasibullina, T. R. Nasibullin, N. A. Krasulina, Individual academic physical education programs for special health groups for physical progress, Teoriya I Praktika Fizicheskoy Kultury, 4, 54-56 (2019)

26. Resolution of the Chief state sanitary doctor of the Russian Federation of 29.12.2010 N189 Moscow « on approval of SanPiN 2.4.2.2821-10» Sanitary and epidemiological requirements for the conditions and organization ofeducation in General education institutions»http://nivanscool.ucoz.ru/dokument/novye_normy_sanpin_dlja_shkolnikov. htm (last accessed: 19.02.2020)

27. J. Shi, J. Shen, J. Xie, J. Zhi, Y. Xu, Chronic fatigue syndrome in Chinese middleschool students, Medicine (United States), 97(4), 9716 (2018) DOI: 10.1097/MD.0000000000009716

28. V. L. Kalmanovich, Positive dynamics of the development of the Russian student sports union and student sports movement in the Russian Federation, Prospects for the development of modern student sports. Results of performances of Russian athletes at the Universiade 2013 in Kazan: Materials of the All-Russian Scientific and Practical Conference, 2013, FROM

29. W. Wilson, Sports infrastructure, legacy and the paradox of the 1984 Olympic games, International Journal of the History of Sport, 32 (1), 144-156 (2015)

30. Z. Sun, A brief analysis of sports venues in colleges and universities, Asian Social Science, 11(16), 114-117 (2015) 